\title{
Adapting to Sea Level Rise: A Law of the Sea Perspective
}

\author{
Sarra Sefrioui
}

\section{Introduction}

A fresh look at the latest satellite data from 2002 and 2014 shows that seas are rising by around $1.4 \mathrm{~mm}$ a year due to thermal expansion rather than $0.7-1 \mathrm{~mm}$ as was expected. ${ }^{1}$ Many geographical coastal features and low-lying island countries appear to be at risk of being deleted from the map in the next decades due to global warming and sea level rise. ${ }^{2}$

The reality of climate change and sea level rise does not only have geographical impacts. It may also generate legal implication of changing baselines, which in turn influences the outer limits of maritime zones. The potential submergence of important base points may potentially lead to the loss of maritime jurisdiction subject to maritime claims and to the loss of jurisdictional rights over valuable resources within these maritime spaces. This could consequently have disastrous economic consequences. ${ }^{3}$

It is important to recall that a coastal State's maritime claims to maritime zones-territorial sea, contiguous zone, exclusive economic zone and continental shelf under the United Nations Convention on the Law of the Sea (UNCLOS) - are measured from baselines except for one of the situations where the outer limits of

\footnotetext{
${ }^{1}$ The Guardian. http://www.theguardian.com/environment/2016/jan/26/sea-level-rise-fromocean-warming-underestimated-scientists-say. Accessed 1st Jul 2016.

${ }^{2}$ Kiribati where 32 islets have already disappeared under the sea, Maldives, Nauru, Kosrae, Marshall islands, Salomon islands, Tuvalu and some areas in the US, For more details about which areas within the contiguous U. S. are most at risk and the potential impact of sea level rise, see https:/coast.noaa.gov/digitalcoast/stories/population-risk.html. 25/09/2016.

${ }^{3}$ Schofield (2009a), p. 70.

S. Sefrioui $(\bowtie)$

Faculty of Law, Abdel Malek Essaâdi University, Tangier, Morocco

e-mail: sarra.sefrioui@gmail.com
} 
continental shelf exceed 200 nautical miles. ${ }^{4}$ Baselines are located at the interface between the land area and sea for the purpose of maritime jurisdiction. They also divide the internal waters of a coastal State from the territorial sea-the most landward of the belts of offshore jurisdiction. The international rights and duties of coastal States and flag States differ substantially between internal waters and the territorial sea as shown above. ${ }^{5}$

Moreover, baselines are quite important to the delimitation of boundaries. In the bilateral delimitation of maritime boundaries, baselines form the starting point in delimitations between adjacent and opposite States with overlapping claims to maritime area-the role of baselines. ${ }^{6}$

However, baselines are facing sea level rise effects and at the same time the silence of UNCLOS to the question whether these baselines and therefore maritime zones-or one of them-shift or remain stable and effective. Case law on maritime delimitation provides little responses.

This article examines the potential effects of sea level rise on baselines, the outer limits of maritime zones, and maritime boundary. It will discuss in the first section the question on how the law of the sea can adapt to sea level rise and what measures can be adopted to address the implications of sea level rise on baselines and the establishment of maritime zones. Therefore, the second section of this chapter will focus on the analysis of the effects of sea level rise on baselines from which the maritime limits and boundaries are determined. The third section will provide the potential legal responses to mitigate the effects of sea level rise regarding baseline alteration and disappearance. It tries to answer the question of whether baselines should be ambulatory or permanently fixed. The result of this study will be presented in the conclusion in the fourth section.

\section{Legal Implication of Sea Level Rise on Baselines from Which Maritime Limits and Boundaries Are Determined}

This section mainly discusses the legal framework of maritime zones and the current legal regime of baselines to contextualize the study before analyzing the legal implication of sea level rise on baselines, which in turn influences the outer limits of maritime zones.

\footnotetext{
${ }^{4}$ International Law Association (2008).

${ }^{5}$ Ibid., p. 4.

${ }^{6}$ Ibid., p. 5. International Law Association referring to the International Court of Justice (ICJ) case ICJ (2009).
} 


\subsection{General Description of Maritime Zones}

According to the United Nations Convention of 10 December 1982 on the Law of the Sea (UNCLOS), maritime zones can be divided mainly into six areas as follows. The internal waters are located on the landward side of the baselines and comprise the maritime waters adjacent to the land territory of the coastal State (article $8 \S$ 1 UNCLOS); the territorial sea is adjacent to the internal waters, and it measures 12 nautical miles from the baseline (articles $2 \S 1$ and 3 UNCLOS); the contiguous zone measured 24 nautical miles from the baseline where coastal State has, notably, policing powers in relation to its customs, fiscal, sanitary and immigration laws, and regulations (article 33 UNCLOS); the exclusive economic zone is 200 nautical miles wide (article 57 UNCLOS) where coastal State has sovereign rights on this zone in respect to environmental protection, scientific research, exploration, and the use of natural resources (article 56 UNCLOS). The continental shelf is the prolongation of the coastal State's land territory submerged for 200 miles from the baselines when the outer edge of the continental margin is less or up to 350 nautical miles (or 100 nautical miles from the $2500 \mathrm{~m}$ isobath) if it is wider (article 76 UNCLOS). However, since the coastal State's right to outer limits of continental shelf relies not only on the 200 nautical miles rule but also on the "natural prolongation" criterion, it implies that the outer limits of the continental shelf must not always be measured from baselines. The coastal State has sovereign rights over this area in respect to the exploration and exploitation of natural resources (article $77 \S 1$ UNCLOS). Finally, the high seas are not subject to the State's sovereignty and are located beyond the external limit of the EEZ (as a maximum of 200 miles from the baselines) (article 86 UNCLOS). The outer limit of all these zones are determined and delimited from baselines except for one of the situations where outer limits of continental shelf exceed 200 nautical miles.

\subsection{Each Maritime Zone Is Measured from Lines Joining Appropriate Points on Land: Baselines}

UNCLOS establishes the legal framework of baselines. However, in some cases, it appears that a distinction between baselines serving for measuring the limits of the maritime zones and baseline serving for establishing maritime boundary can be drawn.

\subsubsection{The Establishment of Baselines Under UNCLOS: Relevant Provisions}

The establishment of baselines is a fundamental operation for a coastal State wishing to have jurisdiction over maritime zones adjacent to the continental coasts. 
These lines are the basis of the coastal State's appropriation of the maritime zones in the sense that it constitutes the lines from which maritime zones are measured. Consequently, baselines are the starting line of the outer limits of maritime zones, and then the significant change on these lines will accordingly affect the jurisdiction of outer limits of maritime zones. They aim to correct the curves of the coast and to prevent their reproduction by enveloping the coast as an "envelope line."7

There are different types of baselines (normal baselines, straight baselines and other bay closing lines, straight line across the mouth of the river) that mainly depend on the general configuration of the coast. A State unilaterally determines the base points that are relevant according to UNCLOS. This national operation ${ }^{8}$ of the unilateral determination of the relevant baselines has, however, international aspects. $^{9}$

\section{Normal Baselines}

The relevant regulation concerning baselines was included in the Geneva Convention $1958^{10}$ and is currently in UNCLOS 1982. Normal baselines are defined by article 5 of UNCLOS as follows: "Except where otherwise provided in this Convention, the normal baseline for measuring the breadth of the territorial sea is the low-water line along the coast as marked on large-scale charts officially recognized by coastal State." Thus, the normal baseline is the low-water line ${ }^{11}$ drawn also according to UNCLOS, including article 6 (reefs), article 8 (internal waters), article 9 (mouths of rivers), article 13 (low-tide elevations). It appears that the coastal State would try to choose the lowest line to establish its baseline far from the coast seaward.

A reference to the method of drawing baselines is made in article 14 of UNCLOS, which underlines that "the coastal State may determine baselines in turn by any of the methods provided for in the foregoing articles to suit different conditions." Therefore, only States have the right to choose the reference level of its

\footnotetext{
${ }^{7}$ Kapoor and Kerr (1986), p. 58.

${ }^{8}$ See, ICJ, Judgment (1951).

${ }^{9}$ ICJ, Judgment (2009), para. 137.

${ }^{10}$ The Geneva Convention in 1958 is one of the four first conventions on the law of the sea matters that has codified, in many provisions, the customary international law.

${ }^{11}$ The low-water line is defined by the International Hydrographic Organization as the line until which water is retreated at low water along the coast in particular in a beach ("[la ligne] jusqu' $a$ laquelle se retire l' eau à basse mer le long de la côte, en particulier sur une plage." It is identified by a "ligne mince et ondulée formée de sable fin, de débris de coquilles, de petits morceaux d'algues, de détritus divers, etc., laissée par les vagues, qui marque la limite supérieure atteinte par leur mouvement sur la plage." Organisation Hydrographique Internationale (1998), p. 41. The different level used to establish a low water line are Lowest Astronomical Tide, LAT, Mean Low Water Springs, MLWS; Mean Lower Low Water, MLLW; Mean Sea Level, MSL. See, United Nations Office for Oceans Affairs and the Law of the Sea (1989), p. 47.
} 
low-water line, and it is submitted to any evaluation. ${ }^{12}$ The majority of States in the world have established normal baselines in a sense that they are considered as the "default" baselines. ${ }^{13}$ However, a straight baseline has a particular regime.

\section{Straight Baselines}

Straight baselines are drawn where a coastline is deeply indented and cut into, or in the presence of a fringe of islands along the coast in its immediate vicinity. They are drawn by joining the appropriate base points on land in accordance with article 7 (1) of UNCLOS. ${ }^{14}$ The straight baselines have the objective to smoothen the curves of the coast. If these baselines are drawn seaward in the coast, their purpose is not, however, to extend the territorial sea unduly. ${ }^{15}$ The International Court of Justice in the Qatar/Bahrain case generally highlighted that "the method of straight baselines, which is an exception to the normal rules for the determination of baselines [...] must be applied restrictively."16

The Convention determines some "rules" for the establishment of the straight baselines in that they are drawn in some situations, including in the presence of "a delta and other natural conditions, the coastline is highly unstable" (article 7 (2) emphasis added). Also, straight baselines must not depart from any appreciable extent from the general direction of the coast, and the sea areas lying within the lines must be sufficiently closely linked to the land domain in order to be subject to the regime of internal waters (article 7(3) UNCLOS). Article 7(4) also stipulates that straight baselines "shall not be drawn to and from low-tide elevations unless lighthouses or similar installations which are permanently above sea level have been built on them or except in instances where the drawing of baselines to and from such elevations has received general international recognition."

The provisions of article 7 of UNCLOS give rise to several comments related to the exact meaning of the terms used. Of particular interest here is that the term "highly unstable" is not clear. The Convention fails to provide any rule related to the change of geography and seems to give a "stable" solution of straight baselines to avoid fluctuation in case of use of normal baselines.

\footnotetext{
${ }^{12}$ See, Calerton and Schofield (2001), pp. 21-23.

${ }^{13}$ Prescott and Schofield (2000), pp. 94-97.

${ }^{14}$ Straight baselines may also be employed across mouths of rivers (Article 9 UNCLOS) and bays (Article $10 \mathrm{UNCLOS}$ ), which is of less interest here.

${ }^{15}$ United Nations Office for Oceans Affairs and the Law of the Sea (1989), p. 39.

${ }^{16}$ ICJ, Judgment (2001), para. 212.
} 


\subsubsection{Baselines in Establishing Maritime Limits and in Drawing Maritime Boundary}

The distinction between maritime limits and maritime boundaries shapes the potential response to sea level rise and therefore whether ambulatory or fixed baselines will have any implication. ${ }^{17}$ To claim jurisdiction over maritime areas, a State may unilaterally establish maritime limits that mark the outer limit of its national jurisdiction measured from baselines. ${ }^{18}$ However, where there are overlapping claims, maritime delimitation boundary is established from baselines.

\section{Maritime Limits}

A coastal State's maritime zone limit is usually the outer limit of this maritime zone and the inner limit of another zone until the 200-nautical-mile limit that makes the end of the exclusive economic zone and the beginning of the high seas. ${ }^{19}$ Maritime limits determine the extent of maritime zones establishing the ending line of the maritime zones seaward. A State can unilaterally determine its maritime limits when they do not overlap with the neighboring State's maritime limits.

According to UNCLOS, coastal States must deposit charts and geographical coordinates that show straight baselines or the outer limits of the territorial sea, the exclusive economic zone, and the continental shelf derived therefrom with the United Nations Secretary-General. However, UNCLOS does not require that baselines must be published in charts and lists of geographical coordinates. ${ }^{20}$ Baselines "shall be shown on charts of a scale or scales adequate for ascertaining their position." ${ }^{21}$ When determining its baselines, a coastal State must take into consideration that it is a national operation that has international aspects. ${ }^{22}$ The validity of baselines can be challenged by other states as it was argued by the ICJ in the AngloNorwegian Ficheries case that it is "a unilateral act, because only the coastal State is competent to undertake it, the validity of the delimitation with regard to other States depends upon international law." ${ }^{23}$ Baselines that serve for identifying maritime limits have international implications since they can be used for maritime

\footnotetext{
${ }^{17}$ Lisztwan (2012), p. 171.

${ }^{18}$ The outer limit is defined as "limite jusqu'à laquelle un État côtier revendique ou peut revendiquer une juridiction spécifique conformément aux dispositions de la Convention. Les limites extérieures de la mer territoriale, de la zone contiguë et de la zone économique exclusive sont constituées par des lignes dont chaque point est séparé du point le plus proche de la ligne de base par une distance égale à la largeur de la zone mesurée (art. 4; art. 33, par. 2 et art. 57)". Division des affaires maritimes et du droit de la mer (2001), p. 142.

${ }^{19}$ See, Caflisch (1985), p. 376.

${ }^{20}$ Article 16 (2) of UNCLOS.

${ }^{21}$ Ibid. (1) of UNCLOS.

${ }^{22}$ ICJ, Judgment (2009), para. 137.

${ }^{23}$ ICJ, Judgment (1951), p. 132.
} 
delimitation. ${ }^{24}$ Therefore, the alteration of baselines from which limits are determined may also influence the maritime delimitation boundary.

\section{Maritime Delimitation}

Where claims to maritime areas overlap, a maritime boundary is measured from a selection of base points that form the starting point from which the maritime boundary between adjacent and opposite States is measured. ${ }^{25}$ States must negotiate and agree on a maritime boundary or reach delimitation through submission to third-party dispute resolution (including the International Tribunal on the Law of the Sea (ITLOS), the ICJ, or an arbitral tribunal ${ }^{26}$ ). The methodology for determining baselines is not provided by UNCLOS, neither by jurisprudence. Moreover, States do not address the potential shift of their baselines that might be caused by sea level rise. It is left to the agreement through negotiation between the States concerned. States, in their agreement, may agree to fix their baselines and maritime limits regardless of any potential change because of sea level rise.

If they fail to find an agreement, article 15 of UNCLOS provides that "where the coasts of two States are opposite or adjacent to each other, neither of the two States is entitled, failing agreement between them to the contrary, to extend its territorial sea beyond the median line every point of which is equidistant from the nearest points on the baselines from which the breadth of the territorial seas of each of the two States is measured." This selection would give to these points the legal status as such and therefore the legal validity. Nevertheless, the Court or the Tribunal most likely "select base points by reference to the physical geography of the relevant coasts." 27 The relevant coasts would be the projections of which overlap with that of another State. They are determined by the Court in the first step of the judicial maritime boundary delimitation that consists of drawing a provisional line. The International Court of Justice in Romania/Ukraine case held that those base points on the relevant coasts should be chosen that "mark a significant change in the direction of the coast, in such a way that the geometrical figure formed by the line connecting all these points reflects the general direction of the coastlines". ${ }^{28}$ Articles of the Convention dealing with maritime delimitation do not, however, address the impact, if any, of shifting coastal geography or any corresponding change in equities.

\footnotetext{
24،"The delimitation of sea areas has always an international aspect”, ICJ, Judgment (1951), p. 132. PCA Award (2006), para. 365, and explicitly in ICJ, Judgment (2009), para. 137.

${ }^{25}$ ICJ, Judgment (2009), para. 137.

${ }^{26}$ Article 287 (1). State Parties may, however, except boundary delimitations from such compulsory procedures. See ibid. article 298(1)(a)(i).

${ }^{27}$ ICJ, Judgment (2009), para. 137.

${ }^{28}$ Ibid., p. 127.
} 


\subsection{Baselines Would Naturally Change Because of Sea Level Rise}

Legal consequences of the sea level rise are difficult to predict with precision. The change in the coast can be in many ways. However, potential examples and situations can be examined. The first situation to address is that when base points and baselines shift (retreat) landward, and the second is when base points and baselines situated on islands, rocks, and low-tide elevations disappear.

\subsubsection{When Baselines Shift Landward}

When coastal States' baselines retreat landward with no overlapping maritime claims, the coastal State would lose part of its territory, and the baseline from which the breath of the maritime zones is measured would shift landward. With regard to the maritime zone limits unilaterally established, they would also retreat in the same way as the baseline. Therefore, the legal status of the maritime zones would change: part of the territorial sea landward becomes internal water, and seaward becomes EEZ. Therefore, part of the EEZ becomes high seas. This has implications on sovereign rights: innocent passage, freedom of navigation, fishing rights, etc.

When the coastal State has a maritime delimitation agreement with an opposite or adjacent State, this would have two implications:

(a) If the boundary agreement divides their exclusive economic zones, in most cases coastline retreat will only increase the exclusive economic zones of the two States. As such, coastline shift will not affect the types of zones delimited ${ }^{29}$ when the total area of the two EEZs does not exceed 400 nautical miles.

(b) If the total area exceeds 400 nautical miles after the coast retreats, a new area of high seas is created. ${ }^{30}$

Moreover, the shift landward of the baseline may change the initial direction of the coast. In this case, if the retreat is considerable and the distance from the base point and the new base point is significant, this "former base point" would not be "replaced" by a new one because the latter would draw a baseline, which would depart to an appreciable extent from the general direction of the coast, against the spirit of the provision of UNCLOS that "the drawing of baselines must not depart to any appreciable extent from the general direction of the coast" (article 7 (3)). However, the ICJ has faced, in the Nicaragua/Honduras case a highly unstable coastline in Cape Gracias a Dios, where the Nicaragua-Honduras land boundary ends. In this case, if the Delta shifted landward, it would actually lead to the

\footnotetext{
${ }^{29}$ Lisztwan (2012), p. 176.

${ }^{30} \mathrm{Ibid}$.
} 
baseline more closely following the overall shape of the coastline. The Court held that " $[\mathrm{g}]$ iven the close proximity of these base points to each other, any variation or error in situating them would become disproportionately magnified in the resulting equidistance line." ${ }^{31}$ The land boundary along the Rio Coco ends in a prominent delta-Cape Gracias a Dios - created by sediment transported down the river. The parties to the case agreed that the sediment transported by the River Coco has "caused its delta as well as the coastline to the north and south of the Cape, to exhibit a very active morpho-dynamism." 32 The Court has underlined that "continued accretion at the Cape might render any equidistance line so constructed today arbitrary and unreasonable in the near future." ${ }^{33}$ Therefore, the Court did could not determine any base point for the construction of the equidistance line and concluded that "where [...] any base points that could be determined by the Court are inherently unstable, the bisector method may be seen as an approximation of the equidistance method." ${ }^{34}$ However, sea level rise does not only create a shift of baseline landward; it can also submerge islands and low-tide elevations on which base points are established.

\subsubsection{When Base Points Are Situated on Disappeared Island and Low-Tide Elevation}

Islands and low-tide elevations would serve to establish base points and baselines for the purpose of drawing maritime limits and/or maritime boundaries. Therefore, in this section, we will discuss how in some cases the legal regime of an island may change to low-tide elevation regime due to the submergence of the island. Moreover, the distinction of these features implies that coastal States' maritime rights may alter depending on the category into which the maritime feature falls. This could mean a huge loss of coastal States' rights, maritime areas, and resources.

A low-tide elevation is defined by article 13(1) of UNCLOS as an area of land "above water at low-tide but submerged at high tide." The Convention specifies that straight baselines may be drawn to and from low-tide elevations if lighthouses or similar permanently uncovered installations have been constructed on them or if there has been general international recognition (article $7 \S 4$ UNCLOS). However, low-tide elevation may only be used for measuring the breadth of the territorial sea where the low-tide elevation is situated wholly or partly at a distance not exceeding the breadth of the territorial sea from the mainland or an island (article 13 (2) UNCLOS). Therefore, the effect of its disappearance by permanent submergence depends on its geographical situation with respect to the outer limits of the

\footnotetext{
${ }^{31}$ ICJ, Nicaragua/Honduras Case: para. 277.

${ }^{32}$ Ibid.

${ }^{33}$ Ibid.

${ }^{34}$ Ibid.
} 
territorial sea. ${ }^{35}$ It creates a loss of the 12 miles that it generates if it is situated wholly or partly within the territorial sea area. Where a low-tide elevation (or former island) lies at a distance exceeding the breadth of the territorial sea from the mainland or an island, it has no territorial sea of its own (article 13(2) UNCLOS).

It is important to underline that islands are distinguished to be low-tide elevations (article 13(1) UNCLOS). A low-tide elevation is "a naturally formed area of land which is surrounded by and above water at low-tide but submerged at high tide" (article 13(1) UNCLOS), and an island, however, is "a naturally formed area of land, surrounded by water, which is above water at high tide" (article 121 (1) UNCLOS). Islands under article 121 paragraph 1 of UNCLOS remain above water at high tide since it "is a naturally formed area of land, surrounded by water, which is above water at high tide." With regard to the generation of maritime zone, low-tide elevations "literally do not rise to the status of islands." ${ }^{36}$ Islands generate maritime zones such as territorial sea, contiguous zone, EEZ, and continental shelf. Coastal islands are used as baselines when situated within 12 nautical miles and would enlarge the extent of the territorial sea seaward since it generates its own territorial sea. Article 7(4) of UNCLOS recognizes similar rights to low-tide elevations only within its limited circumstances. If sea level rises, some islands may become submerged at least at high tide. This consequently led to a different legal situation with regard to maritime entitlement since islands are different from low-tide elevations.

Therefore, when an island has become a mere low-tide elevation, coastal States would surely try to strengthen against further submersion in order to maintain the straight baseline. ${ }^{37}$ To preserve its emergence above water at low tide, coastal States may engage in some activities of construction of artificial installations on the low-tide elevation. The question that is raised here is to know if these artificial works are legally accepted and do not change the status of the low-tide elevation. To these issue, some scholars (Prescot and $\mathrm{Brid}^{38}$ ) have argued that these activities are not against the provisions of article 7 of the Convention since a low-tide elevation has to be internationally recognized. Nevertheless, in a jurisdictional maritime delimitation, even though the general recognition of a low-tide elevation is one of the conditions to use it to draw straight baselines, it seems difficult to accept that the Court of the Tribunal would still consider a disappeared low-tide elevation. For instance, the International Court of Justice accepted the use by Norway of a nonconstructed low-tide elevation to draw straight baselines, ${ }^{39}$ but these two situations cannot be assimilated.

This would lead to conclude that if the land features from which baselines may be drawn retreat into each other and disappear, there will be no baselines from

\footnotetext{
${ }^{35}$ See, Calerton and Schofield (2001), p. 38.

${ }^{36}$ Roach and Smith (1996), p. 73.

${ }^{37}$ See, Freestone and Pethick (1994).

${ }^{38}$ Bird and Prescott (1989), pp. 177-196.

${ }^{39}$ ICJ, Fisheries Case: 116.
} 
which to define the internal waters, territorial sea, contiguous zone, exclusive economic zone, and continental shelf zone. ${ }^{40}$ With the disappearance of this zones, the maritime area would be subject to the regime of high seas since this regime applies "to all parts of the sea that are not included in the exclusive economic zone, in the territorial sea or in the internal waters of a State, or in the archipelagic waters of an archipelagic State." 41

\section{Potential Responses to Baseline Alteration and Base Point Disappearance}

It is necessary to recall that the legal framework of the United Nations Convention on the Law of the Sea of 1982 is based on maritime geography. However, unlike the Convention, maritime geography is by its nature unstable and evolving. In this context, the question that can be raised is how a lawyer can find legal answers to the questions raised by the instability of the low-water line and some base points and their potential impact on maritime baselines.

The answer to this question is not easy. Two theories have emerged generating different consequences: the approach that encourages the use of ambulatory baselines and the opposite approach, which has opted for the stability and preservation of baselines vis-à-vis the change in geography.

\subsection{The Practical Implications of the Use of Shifting Baselines}

Referring to the above analysis of low water normal baselines of article 5 of UNCLOS, it is understood that there is a common uncertainty related to the coastal State having the choice regarding which one is the low-water line, which is inherently changing by sea level rise. It is to recall that the lower water line is the starting line of the outer limits of maritime zones.

In interpreting article 5 of UNCLOS, the International Law Association' (ILA) Committee on Baselines under the International Law of the Sea has argued that the charted low-water line is the legal normal baseline and the chart itself is the legal document that determines the position of that baseline irrespective of the physical realities of the coast. ${ }^{42}$ As discussing above, the low-water line depends on the choice of vertical datum that is the level of reference for vertical measurements of a tide.

\footnotetext{
${ }^{40}$ See Hestetune (2010).

${ }^{41}$ Article 86 of UNCLOS.

${ }^{42}$ ILA's interpretation of article 5 of the UNCLOS, pp. 1, 2.
} 
Article 5 of LOSC presents another uncertainty in that it does not specify a particular vertical datum and thus low-water line to be used. "With respect to the changes in the location of the low-water line caused by the tidal cycle, this line can be fixed by identifying the single vertical, or tidal, datum (among several used in the hydrographic community) to represent low tide. This vertical datum is the 'zero level' to which elevation and depth measurements are reduced. The intersection of the sea-when it is at that chosen level-with the coast is the low-water line. The low-water line thus defined is an elusive feature if not a purely conceptual construct." 43 Therefore, the choice is left to the coastal State since there is no "wrong" answer. $^{44}$

Once the selected low-water line is shown on the charts officially, there is therefore recognition by coastal States and normal baseline could remain in place, irrespective of sea level rise. This would ensure safety and prevent navigation from uncertainty.

However, another interpretation was given to article 5 of UNCLOS by the ILA in the case of unstable coasts due to sea level rise. Normal baselines could adapt to physical realities, and therefore they could be dynamic. ${ }^{45}$ This means that it would create a baseline system that reflects the actual geographical conditions by being ambulatory. ${ }^{46}$

The ambulatory approach considers that the Convention does not provide any provision on the consequences of sea level rise on the baselines, islands, and low-tide elevations, and consequently nothing can require from a coastal State to permanently fix its limits and boundaries. The very few provisions that might be seen as dealing with stability of maritime limits are related to the continental shelf and with the deltas' baseline provisions, but they are far from being sufficient. Thus, with regard to the continental shelf, UNCLOS requires from the coastal State to "deposit with the Secretary-General of the United Nations charts and relevant information, including geodetic data, permanently describing the outer limits of its continental shelf." 47 As to the baselines of the deltas, UNCLOS provides that "the appropriate points may be selected along the furthest seaward extent of the low-water line and, notwithstanding subsequent regression of the low-water line, the straight baselines shall remain effective until changed by the coastal State in accordance with this Convention." 48

The ambulatory or shifting baseline approach has been developed by some scholars ${ }^{49}$ who consider that with sea level rise uncertainty in maritime boundaries is created in that the baseline from which the boundary is drawn is ambulatory. In

\footnotetext{
${ }^{43}$ Ibid., p. 6.

${ }^{44}$ Calerton and Schofield (2001), p. 14.

${ }^{45}$ Supra note 3 , p. 2.

${ }^{46}$ Ibid., p. 6.

${ }^{47}$ Article 76 paragraph 9 of UNCLOS.

${ }^{48}$ Article 7 paragraph 2 of UNCLOS.

${ }^{49}$ See Caron (1990), p. 635; Di Leva and Morita (2008); Reed (2000).
} 
this sense, when feature from or on which the baseline is drawn disappears, the baseline must move and the maritime boundary generated from it has to be redrawn and calculated from the new baseline. Therefore, the maritime boundary generated from the previous disappeared baseline is not valid anymore and is reestablished from the new baseline. In this case, the outer limits of maritime zones are ambulatory in that they will move with the baselines from which they are measured and normal baselines may change with the change of the low-water line. ${ }^{50}$

The disappearance of baseline point implies the disappearance of the boundary generated by that point. The boundary though follows respectively the "movement" base point and the baseline. It results that maritime limits and boundaries shift when baselines shift, islands, or low-tide elevations disappear.

Some scholars have suggested that the implications of sea level rise on maritime boundaries could lead to "renegotiation of maritime boundary agreements based on the principle of equidistance to correspond with new geographic realities; re-evaluation of both equity and equidistance principles by international courts and tribunals in settling boundary disputes; or finally, reversion of highly disputed exclusive economic zone claims to the legal status of high seas." ${ }^{2}$ This was, for example, the case of the two coastal State neighbors Switzerland and Italy. ${ }^{52}$ The maritime boundary between these States shifts because of the height of the glaciers. Therefore, it was not permanently determined and led the parties between 2008 and 2009 to negotiate the definition of a new maritime boundary. ${ }^{53}$

This shift may generate some critical consequences. It would create uncertainty in maritime boundaries that would not be appreciated by a law that aims to generate stability between States in their relation. Modifying maritime boundaries regularly would create legal insecurity for States that have a constant unstable coast. They would have to constantly review their maritime limits and boundaries, and this would also create conflicts and instability for any neighboring state, even those that have more stable baselines.

In fact, the change of baseline could create conflicts between adjacent or opposite coastal States over the exploitation of natural resources. ${ }^{54}$ If the shift of baseline is to be applied, some States that would lose part of their territory, islands, or low-tide elevations may invest huge financial efforts to maintain them even

\footnotetext{
${ }^{50}$ Alexander (1983), p. 535.

${ }^{51}$ Houghton et al. (2010), pp. 813-814.

${ }^{52}$ The original proposal to move the Swiss-Italian border comes from a member of Italy's centre-left opposition party and the final border will be agreed by a commission of experts from Switzerland's Federal Office of Topography and Italy's Military Geographic Institute. See, https://www. newscientist.com/article/dn16854-climate-changes-europes-borders-and-the-worlds/. See also, http://www.independent.co.uk/news/world/europe/melting-snow-prompts-border-change-betweenswitzerland-and-italy-1653181.html. Accessed on 01/10/2016.

${ }^{53}$ However, the result of this negotiations have not been provided.

${ }^{54}$ Caron (1990), pp. 640-641.
} 
"artificially." 55 On the other side, by adjusting and correcting baselines, coastal States must take into consideration the costs of adaptation and the time that has to be spent in the long process of modifying maritime borders. Moreover, by applying the ambulatory baseline approach and if baselines are not marked on large-scale charts, navigation charts would not be precise in determining the maritime limits and boundaries and ships would not know exactly in which zone they navigate and to which rights they are subject (right of innocent passage, fishing rights, etc.).

In State practice, some States having an unstable baseline have made reference, in their national legislation, to the point on which the base point is situated without indicating the exact geographical coordinates of the point. To avoid the risk of establishment of a baseline that would not be stable, some States did not register their geographical coordinates but are content in the publication of the marine charts, which are formally easier to update with more flexibility in determining base points. For example, the Mexican legislation, in determining base points in the Mexican Golf, indicated that the departure point of the baseline is situated in the middle of the point in the mouth of Rio Grande without adding any precision about the geographical coordinates about this point. ${ }^{56}$

Taking into consideration all these implications of the shifting baseline approach, the ILA argued that the actual low-water line is the legal normal baseline and charts, and it should be considered as the evidence of the physical coastal realities or the actual coastal configuration. ${ }^{57}$ The interpretation of article 5 of UNCLOS by the coastal State is fundamental for addressing the potential impacts of sea level rise with regard to maritime zones.

\subsection{Toward the Preservation of Baselines and Its Practical Implications}

As discussed above, neither in the case of normal baselines nor in straight baselines does UNCLOS provide that the maritime zone limits and boundaries can move with baselines. It "permanently" fixes the outer limit of the continental shelf to every State since they have to deposit to the Secretary-General of the United Nations

\footnotetext{
${ }^{55}$ Ibid., pp. 639-640; Soons (1990), pp. 222-223. Examples can be cited of some states. Indonesia that was planning to construct giant dikes around twelve islands in order to protect its territorial sea. Also, the case of Okinotorishima Island can be cited where the Japan is spending colossal sums to prevent its erosion and thus claim an EEZ. Approximately 163,000 miles of seabed and fishing zone were threatened. It is an island that is isolated from the coastal State, uninhabited and does not have fresh water. The island is a strategic point in the crossroad of the maritime roads converging to the centers of the world development. In 1977, Japan have declared a 200 nautical miles around Okinotorishima (Law No 30 of 2nd May 1977. http://www.un.org/Depts/los/ LEGISLATIONANDTREATIES/PDFFILES/JPN_1977_Law.pdf. Accessed 3rd Mar 2016. See also, Song (2009), pp. 145-176.

${ }^{56}$ Federal Act relating to the Sea, 8 Jan 1986. http://www.un.org/Depts/los/ LEGISLATIONANDTREATIES/PDFFILES/MEX_1986_Act.pdf. Accessed 3rd July 2016.

${ }^{57}$ Supra note 3, p. 2.
} 
charts and relevant information, including geodetic data, permanently describing the outer limits of their continental shelf..$^{58}$ It also fixes the baselines for deltas and other natural conditions that make coastlines highly unstable. Since UNCLOS does not fix the outer boundary of the territorial sea, the contiguous zone, and the EEZ, one may think that these maritime zone boundaries can be ambulatory. However, the unique provision of UNCLOS to the question of instability of geography is illustrated in article 7(2) ${ }^{59}$ It indicates that despite the possible shift of the coast landward, the appropriate points and the straight baselines joining them "shall remain effective until changed by the coastal State." This article would present some help in our contest because it concerns, according to the Convention, the case of "the presence of a delta and other natural conditions the coastline is highly unstable (emphasis added)" (article 7 (2)). Although it is unclear in which case a coast can be considered as highly unstable, the ICJ in the Nicaragua/Honduras case, noting the highly unstable nature of the mouth of the River Coco at the Nicaragua-Honduras land boundary terminus, decided that fixing base points on either bank of the river and using them to construct a provisional equidistance line would be "unduly problematic." 60

However, the Convention is silent about the legal solution for changes of coasts or disappearance of features on which baselines and base points are established. The preservation of baselines and base points approach have been proposed in 1990 by A.H.A. Soons and was followed by several scholars: ${ }^{61}$ "[C]oastal states are entitled, in the case of landward shifting of the baseline as a result of sea level rise, to maintain the outer limits of the territorial sea and of the [exclusive economic zone] where they were located at a certain moment in accordance with the general rules in force at that time. ${ }^{, 62}$ Following this idea, other scholars (Prescott and Schofield) have underlined that some States, such as the United Kingdom and the Netherlands, have considered the nautical chart as the only legal document that defines baselines. In fact, by recognizing that coastline change by the time, the nautical chart or the straight baseline geographical coordinates as deposited in the Secretary-General must remain the reference legal document regardless of the coastline changes.

By fixing permanently the baselines, resource conflicts between States are avoided. It could appear that the coastal State that had less than 200 nautical mile EEZ and has lost part of its coast would gain more maritime resources because its coastline retreats, but all States would not have more than they are entitled to under the Convention. It is important to understand that since the breath of the maritime zones is fixed by UNCLOS, equity considerations impose States to recall that

\footnotetext{
${ }^{58}$ Article 76 paragraph 9 of UNCLOS. See, Freestone and Pethick (1994), pp. 73-90.

${ }^{59}$ Article 7 paragraph 2 UNCLOS indicated that "Where because of the presence of a delta and other natural conditions the coastline is highly unstable, the appropriate points may be selected along the furthest seaward extent of the low-water line and, notwithstanding subsequent regression of the low-water line, the straight baselines shall remain effective until changed by the coastal State in compliance with this Convention."

${ }^{60}$ ICJ, Judgment (2007), para. 273.

${ }^{61}$ See also, Rayfuse (2010).

${ }^{62}$ Soons (1990), p. 225 (emphasis added).
} 
choosing to fix the boundaries or to adjust them with the ambulatory baselines and base points will not allow States to gain more than what they presently possess. ${ }^{63}$

Changing boundaries to adapt to the coastline changes would lead the state to protect the baselines by artificial costly installations. However, fixing baselines would avoid costs of adjustment to constant uncertain changes of the baselines ${ }^{64}$ and costs of nautical maps modifications. ${ }^{65}$

By fixing the boundaries, the principles governing the oceans and those agreed upon related to the maritime zones and maritime boundaries by the States to the Convention in their negotiations are preserved. Fixing (freezing) baselines would promote stability in the location of limits of maritime zones and also in maritime delimitation boundaries—bilateral and multilateral-agreements. And as the ICJ stated in the Temple of Preah Vihear case, "when two countries establish a frontier between them, one of the primary objects is to achieve stability and finality." ${ }^{66}$ The Division of Ocean Affairs' Handbook on Maritime Delimitation underlines that maritime boundary delimitation agreements "have a vocation for permanence and stability." 67

Baselines, because they have legal meaning and not only a geographical meaning, are characterized by legal stability and should not be moving with the geography. The law of the sea in general is the law that governs relations between States in their maritime affairs. ${ }^{68}$ In this sense, what fundamentally interests the law of the sea, including the Convention, is the stability and security of the relations between States, including in their international boundary regime. Even though the particularity of this law is that it is based on geography - in which change and instability are inherent-law is considered the priority because it provides stability and security and answers perfectly to the objectives of the Convention. Thus, in stating factors that States should consider in boundary negotiations, the UN Division for Ocean Affairs and the Law of the Sea advises States not to take into consideration any future geographical or geological shifts and the corresponding impacts on resource distribution or equities. ${ }^{69}$

Moreover, the Law of the Sea Convention is not the sole source of law governing maritime affairs and entitlements. Reference is made to other complementary Conventions that regulate general international law aspects in the law of the sea such as boundary agreements. According to the Vienna Convention for the Law of

\footnotetext{
${ }^{63}$ Caron (1990), p. 16.

${ }^{64}$ Rayfuse (2009), p. 6.

${ }^{65}$ Caron (1990), p. 647.

${ }^{66}$ See, ICJ Merits (1962).

${ }^{67}$ Division for Ocean Affairs and the Law of the Sea (2000), para. 322.

${ }^{68}$ The Preamble of the United Nations Convention for the Law of the Sea underlines that: it establishes a legal order for the seas and oceans which will facilitate international communication, and will promote the peaceful uses of the seas and oceans, the equitable and efficient utilization of their resources, the conservation of their living resources, and the study, protection and preservation of the marine environment.
}

${ }^{69}$ United Nations (2014), pp. 239-322. 
Treaties ${ }^{70}$ stability of boundary agreements is achieved regardless of coastline movement. Even though geography changes and baseline shifts, maritime boundary agreements and their geographical coordinates remain secure and stable. ${ }^{71}$

Article 62 of the Vienna Convention, however, underlines an exception by which a State can unilaterally terminate an agreement because of a fundamental change in circumstances (rebus sic stantibus ${ }^{72}$ or "things standing thus"). In the light of this article, some scholars have considered that a change in the geography would be a fundamental change that justifies the termination of an agreement and therefore its revision or replacement by a new agreement that would take into consideration the new situation. The question that can arise here is as follows: is an involuntary change of circumstances based on geography considered a fundamental change? Can one of the parties invoke article 62 to unilaterally terminate the maritime boundary agreement? The answer must be preceded by a clarification. Both parties know, at the time of conclusion of their maritime boundary agreement, that change of geography is inherent to this kind of agreements and can initially be expected; thus, stable geography is not the "circumstance" that forms the ground of their consent. Therefore, article 62 of the Vienna Convention cannot be invoked, and coastline changes will not affect the maritime boundary agreement. International Courts have not accepted the recognition of the right of unilateral termination, given the importance of the stability of the treaty regime. ${ }^{73}$ Some States like Argentina and Chile have expressly rejected the application of this theory. ${ }^{74}$ Moreover, the terms of article 62(2) of the Vienna Convention explicitly excludes boundary agreements; although it is still debatable by the doctrine if it also applies to maritime boundaries, it stipulated that "[a] fundamental change of circumstances may not be invoked as a ground for terminating or withdrawing from a treaty [...] if the treaty establishes a boundary [...]." 75 The ICJ in the Aegean Sea case implied that maritime boundaries fall within the Article 62(2) exception: "Whether it is a land frontier or a boundary line in the continental shelf that is in question, the process is essentially the same, and inevitably involves the same element of stability and permanence, and is subject to the rule excluding boundary agreements

\footnotetext{
${ }^{70}$ Vienna Convention on the Law of Treaties (1969), p. 331.

${ }^{71}$ See, Lisztwan (2012), pp. 154-200.

${ }^{72}$ Villiger (2009), p. 766.

${ }^{73}$ Gabčíkovo-Nagymaros Project (Hung./Slovk (1997)), p. 7.

${ }^{74}$ Argentina, United Nations Treaty Collection, Accessed on https://treaties.un.org/pages/ ViewDetailsIII.aspx? src $=$ TREATY\&mtdsg_no $=$ XXIII-1\&chapter $=23 \&$ Temp $=$ mtdsg $3 \& c l a n g=$ en\#EndDec (Argentina reservation) "The Argentine Republic does not accept the idea that a fundamental change of circumstances which has occurred with regard to those existing at the time of the conclusion of a treaty, and which was not foreseen by the parties, may be invoked as a ground for terminating or withdrawing from the treaty [...]"; Chile, United Nations Treaty Collection, Accessed on https://treaties.un.org/doc/Publication/UNTS/Volume\%201223/volume-1223-A18232-English_French.pdf (Chile reservation) "The Republic of Chile declares its adherence to the general principle of the immutability of treaties [...] and [...]formulates a reservation relating to the provisions of article 62, paragraphs 1 and 3, of the Convention, which it considers inapplicable to Chile.".

${ }^{75}$ Article 62(2)(a) of the Vienna Convention on the Law of Treaties (1969).
} 
from fundamental change of circumstances." ${ }^{, 76}$ A state would therefore be unlikely to succeed in unilaterally terminating a maritime boundary treaty by invoking the principle of rebus sic stantibus under article 62 of the Vienna Convention. ${ }^{77}$

However, the stability of boundaries and the legal stability are defended by the legal reasoning ${ }^{78}$ even though the approach of fixing baselines is criticized by being inappropriate and insufficient. ${ }^{79}$ Avoiding instability and insecurity in maritime limits and boundaries would lead to fix them as they are situated at the time of agreement between States and at the time of deposit to the UN Secretary-General. Article 76 paragraph 9 of UNCLOS can be applied analogically to fix baselines and boundaries even though the technic of fixing them is not established yet.

\section{Conclusion}

Climate change and sea level rise create important challenges for the international community in general and for coastal States in particular. The consequences of climate change are affecting every State in the world regardless of their level of richness, size of the territory, the power of the State. It is clear that sea level rise will affect coastal States, in the first place and more than the others.

However, it creates also challenges for international law. The different consequences of sea level rise are showing that law has to take this issue into consideration to find a legal response of adaptation. In this sense, to figure out these solutions, States have to realize the effects of climate change and sea level rise, determine their maritime limits and boundaries, and implement the legal approach of stabilizing them.

This article examined how sea level rise is being a threat to baselines and base points from which the maritime limits and boundaries are determined and the "absence" of response of the provisions of the United Nations Convention for the Law of the Sea even though it is the "Constitution of the Oceans." ${ }^{\text {"80 }}$ But this Constitution could not predict all the different situations. Facing sea level rise, baselines can either retreat or lose base points established on low-tide elevations or islands giving light to complex legal consequences and questions of whether to change the coordinates of baselines and therefore of the limits and boundaries and adapt them to the potential new ones or to freeze baselines allowing the stabilization of the limits and maritime boundary agreement.

Despite some critical views over the preservation of baseline approach, it remains the approach that can be applicable and efficient in a way that it responds to the purpose of law and agreement in the sense of being stable.

\footnotetext{
${ }^{76}$ ICJ (1978), para. 85.

${ }^{77}$ Lisztwan (2012), p. 192.

${ }^{78}$ Kamto (2009), p. 492.

${ }^{79}$ Lisztwan (2012), pp. 154-200.

${ }^{80}$ Tommy (1983).
} 
However, it must be noted that the legal approach to cope with the consequences of sea level rise would not change these consequences; it is only an adaptation theory promoting the stabilization of international legal agreements. More efforts have to be engaged to give importance to public and private sectors in the protection of the seas and oceans to reduce implications of sea level rise and to encourage the important role of the contributions of international courts to the determination of some balancing of national, individual, and common interests.

\section{References}

Alexander L (1983) Baseline delimitations and maritime boundaries. V J Int Law 23:503-536

Bird E, Prescott JRV (1989) Rising global sea levels and national maritime claims. Marine Policy Rep 177:177-196

Caflisch L (1985) La délimitation des espaces entre États dont les côtes se font face ou sont adjacentes. In: Dupuy R-J, Vignes D (dir) Traité du nouveau droit de la mer. Paris, Economica, Brulyant, Bruxelles, pp 375-440

Calerton CM, Schofield C (2001) Developments in the technical determination of maritime space: charts, datums, baselines, maritime zones and limits. Maritime Briefing, No 3, I.B.R.U, University of Durham, United Kingdom

Caron D (1990) When law makes climate change worse: rethinking the law of baselines in light of a rising sea level. Ecol Law Q 17:621-653

Di Leva C, Morita S (2008) Maritime rights of coastal states and climate change: should states adapt to submerged boundaries? World Bank Law and Development Working Paper Series No. 5, p 17. http://siteresources.worldbank.org/INTLAWJUSTICE/Resources/L\&D_number5.pdf

Division des affaires maritimes et du droit de la mer (2001) Manuel sur la délimitation des frontières maritimes. United Nations, New York

Division for Ocean Affairs and the Law of the Sea (2000) Handbook on the delimitation of maritime boundaries. United Nations, New York

Dorst L (2008) Hydrographic service of the Royal Netherlands Navy. The effects of changing baselines on the limits of the Netherlands in the North Sea. In: Fifth ABLOS conference: difficulties in implementing the provisions of UNCLOS, 15-17 October 2008. http://www. gmat.unsw.edu.au/ablos/ABLOS08Folder/Session6-Paper3-Dorst.pdf. Accessed 15 July 2016

Federal Act relating to the Sea, 8 Jan 1986. http://www.un.org/Depts/los/ LEGISLATIONANDTREATIES/PDFFILES/MEX_1986_Act.pdf. Accessed 3 July 2016

Freestone D, Pethick J (1994) Sea level rise and maritime boundaries: international implications of impacts and responses. In: Blake GH (ed) Maritime boundaries. World boundaries, vol 5. London, pp 73-90

Hestetune J (2010) The invading waters: climate change dispossession, state extinction, and international law. California Western School of Law

Houghton KJ, Vafeidis AT, Neumann B, Proelss A (2010) Maritime boundaries in a rising sea. Nat Geosci 3:813-816

ICJ, Gabčíkovo-Nagymaros Project (1997) (Hungary/Slovkia)

ICJ, Judgment (1951) Fisheries case (United Kingdom v. Norway)

ICJ, Judgment (1978) Aegean Sea Continental Shelf (Greece v. Turkey)

ICJ, Judgment (2001) Maritime Delimitation and Territorial Question between Qatar and Bahrain (Qatar v. Bahrain)

ICJ, Judgment (2007) Case Concerning Territorial And Maritime Dispute Between Nicaragua and Honduras in The Caribbean Sea (Nicaragua v. Honduras)

ICJ, Judgment (2009) Maritime Delimitation in the Black Sea (Romania v. Ukraine)

International Law Association (2008) Committee on baselines under the law of the sea. Internal Discussion Document 
Kamto M (2009) Sur quelques questions techniques liées à la détermination du tracé d'une frontière maritime délimitée. In: Vignes D, Raigón RC, Cataldi G (dir) L'évolution et l'État actuel du droit international de la mer: Mélanges de droit de la mer offerts. Bruxelles, Bruylant, pp 481-505

Kapoor DC, Kerr AJ (1986) A guide to maritime boundary delimitation. Carswell, Toronto Law No 30 of 2nd May 1977. http://www.un.org/Depts/los/LEGISLATIONANDTREATIES/ PDFFILES/JPN_1977_Law.pdf. Accessed 3 Mar 2016

Lisztwan J (2012) Stability of maritime boundary agreements. Yale J Int Law 37(1):154-200

Organisation Hydrographique Internationale (1998) Dictionnaire hydrographique. Monaco

PCA Award (2006) Arbitration between Barbados and the Republic of Trinidad and Tobago (Barbados/Trinidad and Tobago)

Prescott JRV, Schofield CH (2000) The maritime political boundaries of the world. Martinus Nijhoff, Leiden

Rayfuse R (2009) W(h)ither Tuvalu? International law and disappearing states. In: Symposium International sur les îles et les océans (revised version of the presented document), Paper presented international symposium of Islands and Oceans, Tokyo, Japan, 22-23 January 2009, pp 70-77

Rayfuse R (2010) International law and disappearing states: utilising maritime entitlements to overcome the statehood dilemma, Univ. N.S.W. Faculty of Law Research Series, Paper 52

Reed MW (2000) Shore and sea boundaries. The development of international maritime boundary principles through United States practice, vol 3, p 185

Roach JA, Smith RW (1996) United States responses to excessive maritime claims, 2nd edn

Schofield C (2009a) Against a rising tide: ambulatory baselines and shifting maritime limits. In: International symposium on Islands and Oceans, Tokyo, $\mathrm{p} 70$

Schofield CH (2009b) Against a rising tide: ambulatory baselines and shifting maritime limits in the face of sea level rise. Paper presented at the proceedings of the international symposium of Islands and Oceans, Terashima, Tokyo, Ocean Policy Research Foundation, pp 70-77

Song Y-H (2009) Okinotorishima: a "Rock" or an "Island"?: recent maritime boundary controversy between Japan and Taiwan/China. In Hong S-Y, Van Dyke JM (eds) Maritime boundary disputes, settlement processes and the law of the sea, Publications on ocean development series. Martinus Nijhoff, Leiden, pp 145-176

Soons AHA (1990) The effects of a rising sea level on maritime limits and boundaries. Netherlands Int Law Rev 37(2):207-232

Tommy KTB (1983) Third United Nations Conference on the Law of the Sea, A Constitution for the Oceans (Dec. $6 \&$ 11, 1982), The Law of the Sea: Official Text of The United Nations Convention on the Law of the Sea with Annexes and Index, at xxxiii, xxxiii

United Nations (2014) Handbook on the delimitation of maritime boundaries

United Nations Office for Oceans Affairs and the Law of the Sea (1989) Vienna Convention on the law of treaties, 23 of May 1969, 1155 U.N.T.S. 331

Villiger ME (ed) (2009) Commentary on The 1969 Vienna Convention on the Law of Treaties. Brill/Nijhoff

Open Access This chapter is licensed under the terms of the Creative Commons AttributionNonCommercial 4.0 International License (http://creativecommons.org/licenses/by-nc/4.0/), which permits any noncommercial use, sharing, adaptation, distribution and reproduction in any medium or format, as long as you give appropriate credit to the original author(s) and the source, provide a link to the Creative Commons license and indicate if changes were made.

The images or other third party material in this chapter are included in the chapter's Creative Commons license, unless indicated otherwise in a credit line to the material. If material is not included in the chapter's Creative Commons license and your intended use is not permitted by statutory regulation or exceeds the permitted use, you will need to obtain permission directly from the copyright holder. 